\title{
Due Process And Teacher/Administrator Responsibilities In The United States
}

Daniel T. Cunniff, (E-mail: dcunniff@nu.edu), National University

\begin{abstract}
This paper addressed the need for continued awareness on the part of Educational Administrators as to their legal responsibilities as instructional leaders and custodians of the students under their supervision. Research revealed that school administrators unknowingly are violating the law everyday. Courts are keeping a close eye on school districts, which ignore the fact that they are acting in place of students' parents and cannot overstep their bounds. The author stressed the fact that it is up to school officials to educate themselves as to their legal responsibilities. The study covered key issues including due process, suspension and expulsion, student searches, and sexual harassment. Case studies were cited and suggestions for litigation avoidance offered.
\end{abstract}

\section{INTRODUCTION}

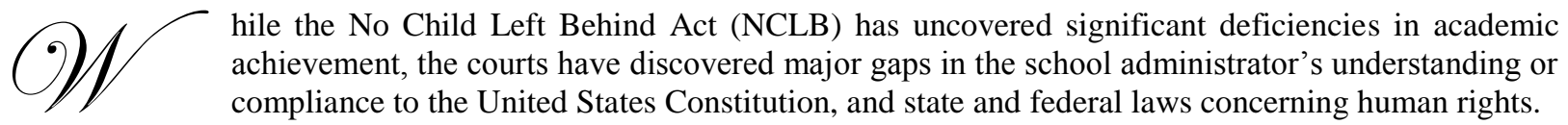

A professional career can be altered with an improper, split-second decision of a school official. Front-line school principals, assistant principals and learning directors as well as teachers must make hundreds of decisions concerning students on a daily basis. Just one wrong action can result in a costly court battle. The late John W. Nicoll wrote in his book So You Want to Be a School Administrator, that administrators and "wanna be" administrators must stay up to date with what is happening with the courts and laws as they pertain to running the schools. With our society becoming more and more litigious, and with America having more lawyers per capita than any other country in the world, lawyers are all looking to sue or defend someone. Every action the administrator takes may easily result in litigation (Nicoll 2003).

Legal activism has found a place in our educational system. Today, there are not only more lawsuits against educators, there are more diverse types of lawsuits aimed at our educational leadership. The best protection is preventative action. Shoop and Dunklee write in their book Anatomy of a Lawsuit, that educators are vulnerable because, like doctors, we deal with our most precious asset, our children. The authors go on to say, as with the medical profession, we are never far removed from the shadow of the courthouse (Shoop \& Dunklee, 2006).

Some of the more common pitfalls facing today's educational administrators and teachers as well, are in loco parentis, suspension and expulsion, student searches, and sexual harassment. The remainder of this paper will focus on these as well as other issues. The conclusion will offer suggestions for the avoidance of litigation.

\section{DUE PROCESS}

It has become clear with the passage of the NCLB Act, that knowledge of federal legislation as well as state statutes is important for school administrators and teachers. Basic legal knowledge is critical because the law impacts every facet of school operations including curricular and extracurricular activities (Reinhartz \& Beach, 2004). 
Arthur Townley reminds us that Due Process is implicit in the Fourth Amendment of the Constitution which states "the right of people to be secure in their persons, houses, papers, and effects, against unreasonable searches and seizures, shall not be violated, and no warrants shall issue, but upon probable cause." This amendment has involved litigation involving searches of student's lockers, drug possession, weapons on campus and teachers' rights to privacy. The author goes on to state that for schools, a pertinent part of the Fifth Amendment guarantees that "no person ... shall be compelled in any criminal case to be a witness against himself, nor be deprived of life, liberty or property, without due process of law; nor shall private property be taken for public use without just compensation" (Townley et al., 2001).

A due process definition used by LaMorte states "Due process of the law implies that the powers of the government are exercised similarly in similar situations in order to protect individual's rights. Denial of this right is prohibited by the Fifth and Fourteenth Amendment when life, liberty, or property are involved (LaMorte, 1999).

Legal scholar and criminologist Herbert Packer describes the criminal justice process in the United States as competition between two value systems representing two ends of value systems. He considers the due process model as the embodiment of traditional liberal values and states "Politically, it (the due process model), embodies traditional liberal values. In this model, the principal goal of criminal justice is at least as much to protect the innocent as it is to convict the guilty." He asserts that from a political standpoint, the crime-control model reflects traditional conservative values focusing on efficiency in the operation of the criminal justice process. Packer describes this model as "assembly-line justice." He goes on to say that speed requires that cases be handled informally and uniformly, minimizing occasions for challenge or appeals (Packer, 1968).

Most school districts prefer to mediate or go to arbitration. Packer believes since the mid-1970s the United States focuses on traditional politically conservative values and dominates the practice of juvenile justice (Packer, 1968). School districts realize the costs involved in litigation and, for the most part, try to settle matters outside of the court system.

\section{IN LOCO PARENTIS}

Any certificated employee of a school district cannot be subject to criminal prosecution if in carrying out their duties providing they exercise the same degree of physical control over the pupil that a parent would be legally privileged to exercise.

In a Los Angeles Times article, a study by Marshall was cited where, in 1995, more than half of the fathers questioned were spending less than five minutes with their children on a typical workday (Marshall, 1995). In loco parentis often stems around discipline issues. Teachers and administrators are frustrated and feel that attempting to contact parents about student misbehavior is non-productive. Townley and others contend that with the increase in one-parent families, teachers find they cannot readily reach the parent by phone, notes sent home with the student are lost, and due to parents personal situations, parents are unable to supervise the students consistently or to offer incentives for positive behavior (Townley et al., 2001).

Taking matters into your own hands is touchy. It is not against any federal law to use corporal punishment. It may be against the law in your state.

Most authorities agree that corporal punishment is defined as infliction of physical pain for misconduct. The Supreme Court in Ingraham v. Wright (1977) made a landmark decision wherein it was held that corporal punishment of students violates neither the Eighth Amendment nor the due process guarantees of the Fourteenth Amendment. The Court held that the Eighth Amendment's prohibition of cruel and unusual punishment applies to criminals only and is not to be applied to disciplining students in public schools.

Most state statutes prohibit corporal punishment. New York allows local boards of education to decide on its application. Of the 23 states that have addressed the problem through legislation, 21 have authorized the moderate use of corporal punishment in public schools (LaMorte, 1999). 
School officials have the right under in loco parentis to search rooms while students are away on school sponsored trips or lockers when they are at school if there is reasonable cause, Webb v. McCullough, 828 F.2d 1151 $\left(6^{\text {th }}\right.$ Cir. 1987) and Kansas v. Stein, 203 Kan. 638, 456 P.2d 1 (1969) respectively.

Any incidents involving students that may have questionable circumstances should be called to the attention of the administration and or the school board. The key piece of advice all experienced school administrators give is to document, document, document.

\section{SUSPENSION AND EXPULSION}

Students may be excluded from school for failure to conform to the school rules or district policy. Suspension or exclusion usually occurs for up to ten days while expulsion is an exclusion from school for the remainder of a quarter to permanent expulsion. Only the school board, not an individual administrator, can expel a student. Courts have ruled that since students have a valuable property interest in attending school, they must be provided due process prior to their being expelled. Able-bodied students may also be transferred, for disciplinary reasons, to another school from the one they usually attend (LaMorte, 1999).

\section{SUSPENSION CASE}

In the case of Goss v. Lopez in 1975 at the Supreme Court of the United States, Justice White delivered the opinion of the Court on the facts that various high school students from the Columbus, Ohio, public school system were denied due process of law contrary to the command of the Fourteenth Amendment in that they were temporarily suspended from their high schools without a hearing either prior to suspension or within a reasonable time thereafter, and enjoined the administrators to remove all references to such suspension from the students' records. The court ruled in favor of the students declaring that each suspension was invalid due to the lack of due process on the part of the school administration.

\section{EXPULSION CASE}

In the case of Gonzales v. McEuen 1977 United States District Court, Central District of California, Takasugi was the District Judge. Eleven high school students were suspended and expelled from Oxnard Union High School following a period of student unrest on campus from October 14-15, 1976. The plaintiffs were charged with having committed certain acts, which it was alleged, led to a riot at Oxnard High School.

The defendants contended that Superintendent McEuen had a negative influence on the board of education during expulsion hearings and the court agreed. The court concluded that the process utilized by the board was fundamentally unfair and raised the presumption of bias.

\section{DISABLED STUDENTS}

Special concerns exist in disciplining children with disabilities. The Individuals with Disabilities Education Act (IDEA) of 1990 and 1997 impose additional legal protections for children with disabilities including a "stayput" provision to protect them from removal from their current placement, which could have a negative impact on their individual education plan (IEP). IDEA does not bind law enforcement agents and judicial authorities in protecting the public and can enforce criminal laws. Students convicted of crimes may be subjected to the same penalties imposed on others convicted of those crimes, including incarceration (LaMorte, 1999).

Public Law 94-142 and the Education for All Handicapped Children Act, approved by Congress in 1975 required all states to establish a free and appropriate education program for students with special needs. It also established procedural safeguards concerning the IEP required for each child. When administrators ignore the provisions of the IEP, they can be in trouble with the federal government. This program has produced more litigation than any other federal education statute enacted into law. 
IDEA has directed states and school districts to include disabled students in regular education programs whenever possible. This has created many teacher and administrator issues. The main ideas of IDEA involve identification and evaluation, zero rejection, personal development, technology-related assistance, free and appropriate public education in the least restrictive environment, and, where necessary, placement in private schools (Townley, 2001). This has been a high-dollar program for all school districts and the root of many court battles.

In Brown v. Board of Education (1954), children with special needs were entitled to free public education. This established clear action plans for disabled students attending school. In 1990, the Americans with Disabilities Act (ADA) expanded legislation into the private sector. Before 1954, many special needs children were not receiving an education at all. It was made clear with this decision that there is a difference in the education needed by students with particular disabilities (Yell, 1998).

\section{STUDENT SEARCHES}

The United States Supreme Court addressed the student search issue in New Jersey v. T.L.O. in 1985. Here the court established a two-prong test determining the reasonableness of a search and was it "justified at its inception." Also, was it reasonably related in scope to the circumstances, which justified the interference in the first place (LaMorte, 1999)?

Educational administrators will always be faced with issues such as stolen money, weapons, or drugs, and may be prone to intrusive searches. The courts have upheld many of these searches, including strip searches as evidenced by Jenkins v. Talladega City Board of Education, 115 F.3d 821 (11 ${ }^{\text {th }}$ Cir. 1997) and Williams v. Ellington, 936 F.2d 881 ( $6^{\text {th }}$ Cir. 1991). The courts state that school officials need discretionary authority to function with efficiency and speed in certain situations. Drug-detecting dogs, and nude searches have all come under court renderings including the right of an administrator to detect child-abuse situations as in Doe v. Renfrow in 1980 and Picarella v. Terrizzi in 1995 respectively (LaMorte, 1999).

School leaders are responsible for the safety of students in their care. They must maintain order and discipline on campus as they are confronted with decisions whether or not to search a student's back pack, locker, desk, coat, or automobile. Administrators must keep in mind that the Fourth Amendment of the United States Constitution guarantees citizens the right "to be secure in their persons, houses, papers and effects, against unreasonable searches and seizures." The administrator must have probable cause to search students, "reasonable suspicion" as a reason for a search (Townley, 2001).

\section{SEXUAL HARASSMENT}

Name calling, assault, verbal harassment, visually derogatory drawings, cartoons, or posters, and unwanted sexual advances are all behaviors that can result in a sexual harassment suit. Every administrator should be aware of what sexual harassment is, what steps to take if harassment takes place, and what the state law says about prohibiting retaliation for reporting sexual harassment. Today, sexual harassment may take place in person or on the internet. School administrators have informed the authors that web sites such as "MySpace" have led to numerous incidences of student violence and suicide. Administrators and teachers have sued school districts, students, and their parents over embarrassing and threatening content posted on personal websites or sent via e-mail. In Scranton, Pennsylvania, a teacher sued the Abington Heights School District for failing to adequately provide for his safety when a student posted a "secret assassination plan" on a website. In San Antonio, Texas, an assistant principal sued several students who posted obscene comments and photos with her name on MySpace.com. (Carr, 2007). Imber and van Geel note that sexual harassment is nonpermissible conduct that had its origins in employment law. Harassment based on sex is a violation of Title VII of the Civil Rights Act of 1964, and federal law makes it unlawful for any employer "to discriminate against any individual because of such individual's race, color, religion, sex, or national origin (Imber \& Geel, 2000). This act carries over to the public schools as well. Washington State Senator Jeanne Kohl-Welles, issued a news release in March of 2007 saying that today there are more ways than ever for today's youth to intimidate each other, through cell phones and the Internet, with instant messaging, text messaging and setting up imposter Web sites (such as MySpace.com). The Senator states, "Cyberspace has become 
a real-life extension of playing video games. Cyber bullying is on the rise, thanks to the explosion of technology." Senator Jeanne Kohl-Welles has sponsored Senate Bill 5288, which would create non-tolerance of cyber bullying in public school (Kohl-Welles, 2007).

With this kind of legislation on the horizon, it seems to beg school districts to adopt their own policy prohibiting the harassment of any student, including electronic bullying. Senator Kohl-Welles emphasizes the importance of these laws and policies by stating, "With the often anonymous nature of cyber bullying and with consequences as tragic as suicide, we need to tackle these problems now" (Kohl-Welles, 2007).

Students and parents of students have looked to the courts for relief from sexual harassment in the schools. Peer sexual harassment can have a major negative impact on the life of a student. In the case of Davis v. Monroe (1996), a female student complained that a fellow male student was sexually harassing her and the school officials did not take appropriate action to address the issue. The court agreed, and the school officials were held liable for their indifference (Reinhartz \& Beach, 2004).

Because of the sensitive nature of sexual harassment, the U.S. Department of Education has ensured confidentiality through the Family Educational Rights and Privacy Act (FERPA) that the best way to avoid sexual harassment claims is to establish good policies and guidelines to enforce them (Hairston, 1998).

\section{LITIGATION AVOIDANCE}

With the many changes in our culture and the advent of technology, numerous conflicts have been created challenging our school leadership. Special issues require new laws and to practice preventative law, it is important that leaders maintain a working knowledge of current laws that affect education. Administrators must take the time to read, and keep current on legislation. Shoop and Dunklee contend that many school districts tend to down play the significance of legal problems, seeking answers at the operational level rather than at the organizational level. They rely on legal counsel only after they have gotten into problems. Administrators can significantly reduce exposure to liability by practicing preventative law such as:

- Understanding the substance of law and knowledge of current education litigation decisions

- Using the proper application of procedures, informed decision making and foreseeability to reduce liability

- $\quad$ Working with counsel at district expense

- $\quad$ Being flexible in conflict resolution to avoid litigation

- $\quad$ Having knowledge of precedent and constitutional compliance

- $\quad$ Taking an active role in preventative law with your staff

The authors of Anatomy of a Lawsuit state "Given the many decisions you make on a daily basis, the quality of your judgment can spell the difference between a safe and supportive learning environment and an environment that is ripe for legal intervention." (Shoop \& Dunklee, 2006).

\section{CONCLUSION}

This paper covered some of the key issues facing today's educational administrator involving civil law. Cases involving due process, suspension, student searchers and harassment were cited as issues brought to the courts by the school districts or private parties to enforce a right or to seek payment for a wrongdoing. The basis for many suits has been the absence of due process. The key for administrators is to provide students or teachers with notice of the charges brought against them and be provided with a chance to present his or her side of the dispute. The author discussed in loco parentis and the role of corporal punishment in our school systems. Suspension and expulsion cases reflected the need for school leaders to educate themselves and seek counsel when faced with these situations.

Preventive law was discussed and the need for administrators to be proactive with staff and their personal development. The key word here was "document" all your actions when you suspect an issue may arise. Student searches were addressed as yet another pitfall for school leaders and case studies were cited. A full understanding of 
the Constitution and the ten amendments known as the Bill of Rights is in order for school administrators and should be emphasized in our certificated training programs. In particular, the First, Fourth, Fifth, Eighth, Tenth, and Fourteenth Amendments should be reviewed by school administrators and their staffs as they develop policies to safeguard their students as well as protect their school districts and themselves.

\section{ABOUT THE AUTHOR}

Dr. Cunniff is the Lead Faculty for Educational Administration at National University's Fresno, California, campus. He received his B.S. and M.A. from Northern Illinois University and his Ph.D. from Walden University. He has taught at Portland State University and California State University in San Marcos. He was the recipient of a 2006 President's Professoriate Award for outstanding contributions "above and beyond" his regular work assignments presented by the Chancellor of National University. As an international business analyst, he was an independent consultant to major Fortune 500 companies, including organizations in Indonesia and Canada. He was an Assistant Superintendent for Secondary Education in Fairbanks, Alaska; Educational Advisor of Education Television in American Samoa; Principal and Acting Superintendent in San Diego County; and an Elementary Principal and teacher in the Chicago suburbs. Dr. Cunniff is also the Coordinator of the International Academic Professor Exchange Program for National University, which is based in La Jolla, California. This position has enabled him to present papers on various educational and business topics at conferences in Panama City, Panama; Belfast, Northern Ireland; and Toronto, Canada.

\section{REFERENCES}

1. Carr, N. (2007, March). American School Board Journal. pg 48-49. National School Boards Association.

2. Hairston, J.B (1998). Sexual harassment in the workplace: New guidance from the federal courts. Texas School Administrator's Legal Digest, 14, 1-7, 20.

3. Imber, M. \& van Gell, T. (2000). Education law ( ${ }^{\text {nd }}$ ed). London: Lawrence Erlbaum and Associates.

4. Kohl-Welles, J., (2007, March 2). Throwing sticks and stones in cyberspace. US Fed News Service, Including US State News. Washington, D.C.

5. LaMorte. Michael W. (1999). School law: cases and concepts. Boston. Allyn and Bacon.

6. Marshall, T. (1995, July 18). A world of pressures on parents, children. Los Angeles Times.

7. Nicoll, John W. (2003). So You Want to Be An Administrator. Sacramento. School Services of California.

8. Packer, Herbert. (1968). The Limits of the Criminal Sanction. Stanford, CA: Stanford University Press.

9. Picciano, Anthony G. (2006). Educational leadership and planning for technology. 4th ed. Upper Saddle River, NJ. Pearson Prentice Hall.

10. Reinhartz, Judy, \& Beach, Don M. (2004). Educational leadership. Boston. Pearson Education, Inc.

11. Shoop, Robert J., Dunklee, Dennis R. (2006). Anatomy of a lawsuit. Thousand Oaks, CA. Corwin Press.

12. Townley, Arthur J., Schmieder-Ramirez, June H., Wehmeyer, Lillian B., \& Lane, Kenneth E. (2001). School law: a California perspective. Dubuque, IA. Kendall/Hunt Publishing Company.

13. Yell, M.L. (1998). The law and special education. Upper Saddle River, NJ. Merrill.

\section{SUGGESTED READING}

1. Dunklee, Dennis R., Shoop, Robert J. (2006). The principal's quick-reference guide to school law: reducing liability, litigation, and other potential legal tangles. Thousand Oaks, CA. Corwin Press. ISBN: 978-1412925945.

2. Osborne, Allan G., Russo, Charles J. (2006). Special education and the law: a guide for practitioners. Thousand Oaks, CA. Corwin Press. ISBN: 978-1412926232.

3. Streshly, William A., Frase, Larry E. (2001). Avoiding legal hassles. Thousand Oaks, CA. Corwin Press. ISBN: 978-0761945307. 